\title{
[2]Rotaxane Formation by Transition State Stabilization
}

DOI:

10.1021/jacs.7b05640

\section{Document Version}

Accepted author manuscript

Link to publication record in Manchester Research Explorer

\section{Citation for published version (APA):}

De Bo, G., Dolphijn, G., Mcternan, C., \& Leigh, D. (2017). [2]Rotaxane Formation by Transition State Stabilization. Journal of the American Chemical Society. https://doi.org/10.1021/jacs.7b05640

\section{Published in:}

Journal of the American Chemical Society

\section{Citing this paper}

Please note that where the full-text provided on Manchester Research Explorer is the Author Accepted Manuscript or Proof version this may differ from the final Published version. If citing, it is advised that you check and use the publisher's definitive version.

\section{General rights}

Copyright and moral rights for the publications made accessible in the Research Explorer are retained by the authors and/or other copyright owners and it is a condition of accessing publications that users recognise and abide by the legal requirements associated with these rights.

\section{Takedown policy}

If you believe that this document breaches copyright please refer to the University of Manchester's Takedown Procedures [http://man.ac.uk/04Y6Bo] or contact uml.scholarlycommunications@manchester.ac.uk providing relevant details, so we can investigate your claim.

\section{OPEN ACCESS}




\title{
[2]Rotaxane Formation by Transition State Stabilization
}

\author{
Guillaume De Bo, Guillaume Dolphijn, Charlie T. McTernan and David A. Leigh* \\ School of Chemistry, University of Manchester, Oxford Road, Manchester, M13 9PL, United Kingdom
}

\section{Supporting Information Placeholder}

ABSTRACT: We report on the synthesis of [2] rotaxanes driven by stabilization of the axleforming transition state. A bifunctional macrocycle, with hydrogen bond donors at one end and acceptors at the other, is used to stabilize the charges that develop during the addition of a primary amine to a cyclic sulfate.

Most rotaxanes are formed by exploiting permanent recognition motifs in the components that subsequently 'live on' in the interlocked product. ${ }^{1}$ Examples of rotaxanes formed through complexdriven effective molarity increases or solvation effects have also been described, ${ }^{2}$ and active template synthesis, ${ }^{3}$ in which metal ions act as both an organizing template and as a catalyst for the reaction used to covalently capture the threaded structure, enables rotaxanes to be assembled under kinetic control. Here we describe the reagent-less formation of a [2] rotaxane driven by transition state stabilization of an activated complex arising from the opening of a cyclic sulfate by a primary amine. ${ }^{4}$

We reasoned that an appropriate bifunctional macrocycle might be able to stabilize the charges developing during the addition of an amine to a cyclic sulfate ( $\ddagger$, Scheme 1$)$. By utilizing such a process, it seemed that a rotaxane (e.g. 1, Scheme 1) could be assembled directly from three components, macrocycle 2 and axle building blocks 3 and 4 , without the need for additional reagents.

Macrocycle 2 contains both a hydrogen bond donor unit (pyridyl-2,6-dicarboxyamide ${ }^{5}$ ) and a hydrogen bond acceptor crown ether-like region (Scheme 1). This makes it a potential receptor for dual hydrogen bond donor-acceptor guests ${ }^{6}$ and complementary to both the transition state and the product of nucleophile addition to a cyclic sulfate. In the presence of the macrocycle the tetrahedral geometry of the cyclic sulfate should lead to an endotopic complex in which the axle of the building block is held perpendicular to the plane of the macrocycle. The angle of attack required for a nucleophile to open a cyclic sulfate ${ }^{7}$ would necessitate the amine approaching from the opposite face of the sulfatecomplexed macrocycle, leading to a threaded (i.e. rotaxane) product (Scheme 1).

\section{Scheme 1. Rotaxane formation by transition} state stabilization

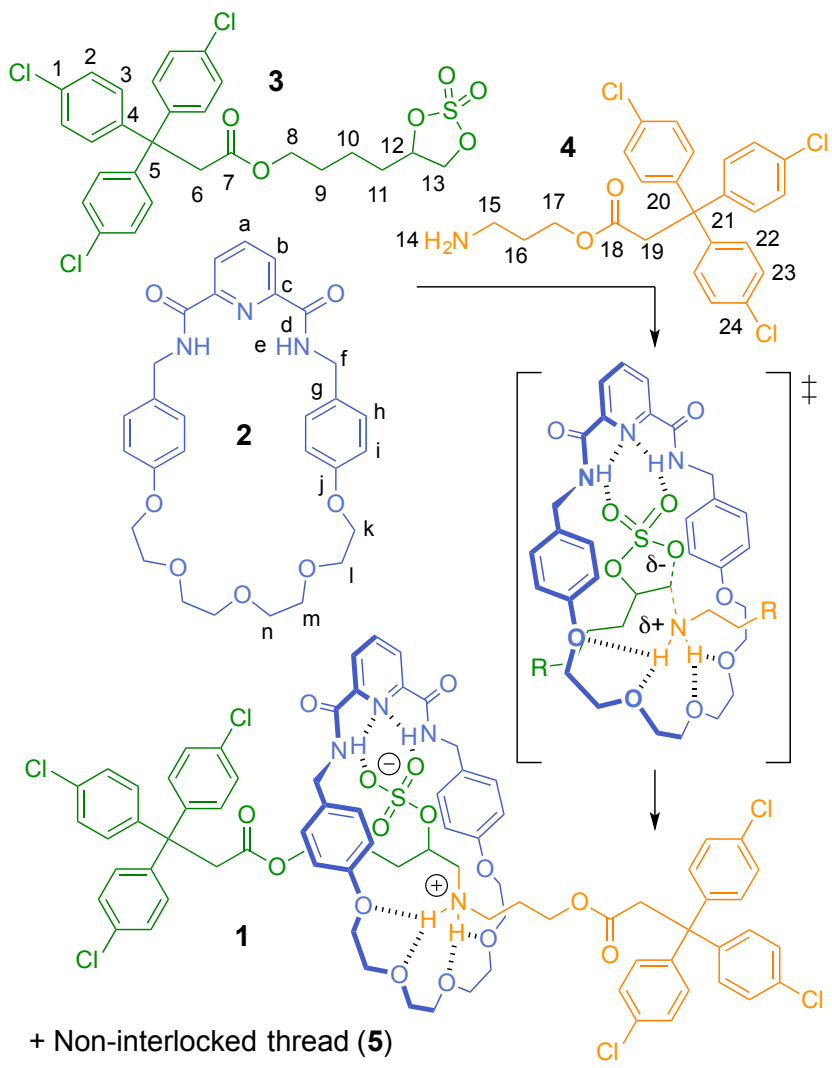

We were delighted by our initial finding that mixing cyclic sulfate 3, macrocycle 2 and amine 4 in a 1:3:1 ratio in $\mathrm{CDCl}_{3}$ led, after 7 days at room temperature, to rotaxane $\mathbf{1}$ in $24 \%$ yield, accompanied by 
some formation of the non-interlocked thread, 5 (entry 1, Table 1). Performing the reaction at higher temperature significantly increased the rate of the background thread-forming reaction (entries 2 and 3, Table 1). Increasing the reaction concentration afforded the rotaxane in higher yield with shorter reaction times (entry 4, Table 1 ). However, the increase in concentration is limited by the solubility of the macrocycle ( 0.2 $\mathrm{M}$ in $\left.\mathrm{CDCl}_{3}\right)$. Using a five-fold excess of the axle components relative to the macrocycle led to complete conversion of the cyclic sulfate with $50 \%$ of the macrocycle incorporated into rotaxane $\mathbf{1}$ (entry 5, Table 1 ). Performing the reaction at lower temperature favors the formation of rotaxane over the free-thread (entries 6 and 7 , Table 1) and, with an initial concentration of $0.7 \mathrm{M} 3_{3}$ and 4, $70 \%$ of macrocycle 2 is converted into rotaxane 1 after five days at $8{ }^{\circ} \mathrm{C}$ (6o \% after 2 days, entry 8 , Table 1).

Table 1. Variations in the Experimental Conditions and Reactants Stoichiometry for the Synthesis of [2] Rotaxane $\mathbf{1}^{\mathrm{a}}$

\begin{tabular}{|c|c|c|c|c|c|c|}
\hline $\begin{array}{c}\text { En- } \\
\text { try }\end{array}$ & $\begin{array}{c}\text { Equiv } \\
\text { of } 2\end{array}$ & $\begin{array}{c}\mathrm{T} \\
\left({ }^{\circ} \mathrm{C}\right)\end{array}$ & $\begin{array}{c}\text { Conc of } \\
3(\mathrm{M})\end{array}$ & $\begin{array}{c}\text { Time } \\
(\mathrm{d})\end{array}$ & $\begin{array}{c}\text { Conv } \\
\text { of } 3 \\
(\%)\end{array}$ & $\begin{array}{c}\text { Conv to } \\
\text { rotaxane } \\
\mathbf{1}(\%)\end{array}$ \\
\hline 1 & 3 & 20 & 0.07 & 6 & 72 & 24 \\
\hline 2 & 3 & 40 & 0.07 & 2 & 76 & 23 \\
\hline 3 & 3 & 60 & 0.07 & 1 & 81 & 15 \\
\hline 4 & 1.5 & 20 & 0.14 & 2 & 81 & 27 \\
\hline 5 & 0.2 & 20 & 1.05 & 1.7 & 100 & 50 \\
\hline 6 & 0.2 & 8 & 1.05 & 0.9 & 94 & 64 \\
\hline 7 & 0.2 & 20 & 0.70 & 0.9 & 90 & 57 \\
\hline 8 & 0.2 & 8 & 0.70 & 5 & 86 & 70 \\
\hline
\end{tabular}

${ }^{a}$ Reactions carried with 3 (1.o equiv) and 4 (1.o equiv) in $\mathrm{CDCl}_{3}$. See Supporting Information for experimental procedure.

The ${ }^{1} \mathrm{H}$ NMR spectra (Figure 1 ) of the macrocycle (2), thread (5) and rotaxane (1) confirms the interlocked architecture, and that the macrocycle binds to both the sulfate and the ammonium moieties in the interlocked product. The downfield shift of the $\mathrm{H}_{\mathrm{e}}$ amide protons in the rotaxane compared to the parent macrocycle $\left(\Delta \delta \mathrm{H}_{\mathrm{e}}=1.04 \mathrm{ppm}\right)$ and the shifts of the protons on the central region of the polyether chain $\left(\Delta \delta \mathrm{H}_{1}=-0.16 \mathrm{ppm} ; \Delta \delta \mathrm{H}_{\mathrm{m}, \mathrm{n}}=-0.07 \mathrm{ppm}\right)$ are indicative of hydrogen bonding between the macrocycle and the sulfate anion and the ammonium cation, respectively. Protons of the backbone of the thread are shifted upfield in the rotaxane $\left(\Delta \delta \mathrm{H}_{12}=-\right.$ $0.45 \mathrm{ppm} ; \Delta \delta \mathrm{H}_{13}=-0.38 \mathrm{ppm} ; \Delta \delta \mathrm{H}_{15}=-0.60 \mathrm{ppm}$; $\left.\Delta \delta \mathrm{H}_{16}=-0.66 \mathrm{ppm} ; \Delta \delta \mathrm{H}_{17}=-0.82 \mathrm{ppm}\right)$ due to the shielding effect of aromatic rings of the macrocycle. Diastereotopic splitting of macrocycle protons $\mathrm{H}_{\mathrm{f}}$ and $\mathrm{H}_{\mathrm{k}}$ occur in the rotaxane as a result of the asymmetry of the threaded axle.

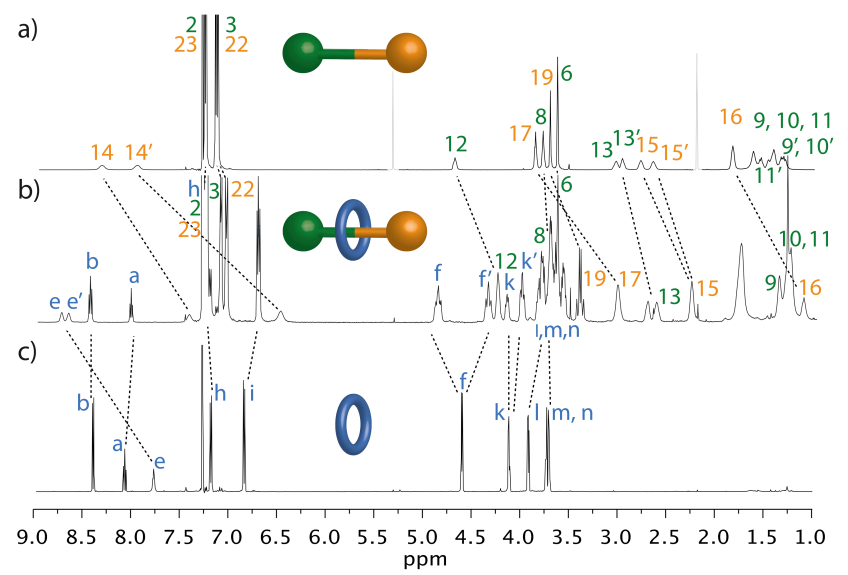

Figure 1. ${ }^{1} \mathrm{H}$ NMR spectra (6oo $\mathrm{MHz}, \mathrm{CDCl}_{3}, 298 \mathrm{~K}$ ) of (a) thread 5, (b) [2] rotaxane 1, (c) macrocycle 2. The assignments correspond to the lettering shown in Scheme 1.

The DFT energy-minimized structure of rotaxane 1 (Figure 2, see Supporting Information for details) shows an excellent fit between the macrocycle and the aminoethyl sulfate unit, and confirms the hydrogen bond interactions between the pyridyl-2,6dicarboxyamide and the sulfate anion, and the crown ether and the ammonium group.

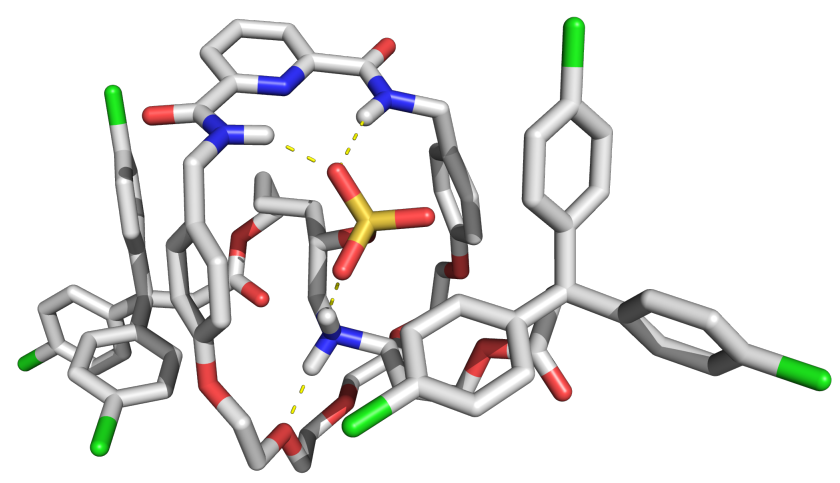

Figure 2. Energy-minimized (DFT B3 $2 \mathrm{LP} / 6-31 \mathrm{G}^{*}$ ) structure of [2] rotaxane $\mathbf{1 .}$

Macrocycle 2 forms only weak complexes with either of the other reaction partners $\left(K_{\mathrm{a}} 25 \mathrm{M}^{-1}\right.$ with 4 , no detectable binding to 3 ; see Supporting Information), meaning that a classical 'passive template' process for rotaxane formation cannot operate. Instead rotaxane formation likely proceeds via the formation of an initially weak complex between 2 and 4 that progressively strengthens during nucleo- 
phile addition to 3 as the macrocycle stabilizes both positive and negative charges developing during the course of the reaction. Hence the macrocycle acts as both a template, preorganizing one (or both) component(s) in a reactive co-conformation, and as a catalyst, stabilizing the transition state of the reaction, in a manner reminiscent of active template synthesis. ${ }^{3 \mathrm{~b}}$

This mechanism is supported by the observation that only free-thread $\mathbf{5}$ is produced when using macrocycle 6 bearing an alkyl chain instead of the crown-ether region (entries 1 and 2, Table 2). Macrocycle 7 , lacking the hydrogen bond donor motif, does produce rotaxane (9) in an analogous reaction (entries 3 and 4 , Table 2 ) but in much lower yield than macrocycle 2 (entries 5 and 6, Table 2). The results demonstrate the importance of the bifunctional structure of the macrocycle used to promote rotaxane formation.

Table 2. Influence of Macrocycle Structure on Rotaxane Formation

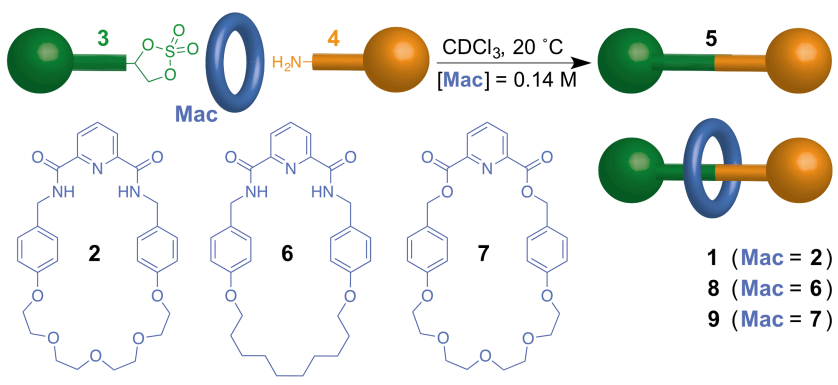

\begin{tabular}{|c|c|c|c|c|c|}
\hline Entry & Mac & $\begin{array}{c}\text { Equiv of } \\
3 \text { and } 4\end{array}$ & $\begin{array}{c}\text { Time } \\
\text { (h) }\end{array}$ & $\begin{array}{c}\text { Conv of } \\
3(\%)\end{array}$ & $\begin{array}{c}\text { Conv to } \\
\text { rotaxane } \\
(\%)\end{array}$ \\
\hline 1 & \multirow{2}{*}{6} & 0.6 & 26 & 36 & o \\
\hline 2 & & 5 & 26 & 75 & o \\
\hline 3 & \multirow{2}{*}{7} & 0.6 & 26 & 32 & 5 \\
\hline 4 & & 5 & 26 & 77 & 25 \\
\hline 5 & \multirow{2}{*}{2} & 0.6 & 48 & 81 & 27 \\
\hline 6 & & 5 & 22 & 90 & 57 \\
\hline
\end{tabular}

The reagent-free synthesis of rotaxanes via transition state stabilization complements existing strategies for the assembly of mechanically interlocked architectures. ${ }^{1}$ The concept may be applicable to a variety of reactions that feature polar transition states.

\section{ASSOCIATED CONTENT}

Supporting Information. Detailed descriptions of synthetic procedures, characterization of new compounds, and spec- troscopic data. This material is available free of charge via the Internet at http://pubs.acs.org.

\section{AUTHOR INFORMATION}

\section{Corresponding Author}

*david.leigh@manchester.ac.uk

\section{ACKNOWLEDGMENTS}

This research was funded by the Engineering and Physical Sciences Research Council (UK). We thank the EPSRC National Mass Spectrometry Centre (Swansea, UK) for high resolution mass spectrometry, Euticals Gmbh for a generous donation of $\mathrm{n}$ propanephosphonic acid anhydride, and the Royal Society for a University Research Fellowship (to G.D.B.) and Research Professorship (to D.A.L.).

\section{REFERENCES}

(1) (a) Xue, M.; Yang, Y.; Chi, X.; Yan, X.; Huang, F. Chem. Rev. 2015, 115, 7398-7501. (b) Bruns, C. J.; Stoddart, J. F. The Nature of the Mechanical Bond: From Molecules to Machines (John Wiley \& Sons, Hoboken, NJ, 2017).

(2) (a) Mock, W. L.; Irra, T. A.; Wepsiec, J. P.; Adhya, M. J. Org. Chem. 1989, 54, 5302-5308. (b) Tuncel, D.; Steinke, J. H. G. Chem. Commun. 1999, 1509-1510. (c) Hübner, G. M.; Gläser, J.; Seel, C.; Vögtle, F. Angew. Chem. Int. Ed. 1999, 38, 383-386. (d) Reuter, C.; Wienand, W.; Hübner, G. M.; Seel, C.; Vögtle, F. Chem. Eur. J. 1999, 5, 2692-2697. (e) Reuter, C.; Vögtle, F. Org. Lett. 20oo, 2, 593-595. (f) Hübner, G. M.; Reuter, C.; Seel, C.; Vögtle, F. Synthesis 200o, 103-108. (g) Tuncel, D.; Steinke, J. H. G. Chem. Commun. 2002, 496-497. (h) Tuncel, D.; Steinke, J. H. G. Macromolecules 2004, 37, 288-302. (i) Ke, C.; Smaldone, R. A.; Kikuchi, T.; Li, H.; Davis, A. P.; Stoddart, J. F. Angew. Chem. Int. Ed. 2013, 52, 381-387. (j) Ke, C.; Strutt, N. L.; Li, H.; Hou, X.; Hartlieb, K. J.; McGonigal, P. R.; Ma, Z.; Iehl, J.; Stern, C. L.; Cheng, C.; Zhu, Z.; Vermeulen, N. A.; Meade, T. J.; Botros, Y. Y.; Stoddart, J. F. J. Am. Chem. Soc. 2013, 135, 17019-17030. (k) Hou, X.; Ke, C.; Cheng, C.; Song, N.; Blackburn, A. K.; Sarjeant, A. A.; Botros, Y. Y.; Yang, Y.-W.; Stoddart, J. F. Chem. Commun. 2014, 5o, 6196-6199. (l) Hou, X.; Ke, C.; Bruns, C. J.; McGonigal, P. R.; Pettman, R. B.; Stoddart, J. F. Nat. Commun. 2015, 6, 6884. (m) Orlandini, G.; Ragazzon, G.; Zanichelli, V.; Secchi, A.; Silvi, S.; Venturi, M.; Arduini, A.; Credi, A. Chem. Commun. 2017, 53, 6172-6174.

(3) (a) Aucagne, V.; Hänni, K. D.; Leigh, D. A.; Lusby, P. J.; Walker, D. B. J. Am. Chem. Soc. 2oo6, 128, 2186-2187. (b) Crowley, J. D.; Goldup, S. M.; Lee, A.-L.; Leigh, D. A.; McBurney, R. T. Chem. Soc. Rev. 2009, 38, 1530-1541. For recent examples of active template synthesis, see: (c) Neal, E. A.; Goldup, S. M. Chem. Sci. 2015, 6, 2398-2404. (d) Barat, R.; Legigan, T.; Tranoy-Opalinski, I.; Renoux, B.; Peraudeau, E.; Clarhaut, J.; Poinot, P.; Fernandes, A. E.; Aucagne, V.; Leigh, D. A.; Papot, S. Chem. Sci. 2015, 6, 2608-2613. (e) Hoekman, S.; Kitching, M. O.; Leigh, D. A.; Papmeyer, M.; Roke, D. J. Am. Chem. Soc. 2015, 137, 7656-7659. (f) Franz, M.; Januszewski, J. A.; Wendinger, D.; Neiss, C.; Movsisyan, L. D.; Hampel, F.; Anderson, H. L.; Görling, A.; Tykwinski, R. R. Angew. Chem. Int. Ed. 2015, 54, 6645-6649. (g) Galli, M.; Lewis, J. E. M.; Goldup, S. M. Angew. Chem. Int. Ed. 2015, 54, 13545-13549. (h) Langton, M. J.; Xiong, Y.; Beer, P. D. Chem. Eur. J. 2015, 21, 18910-18914. (i) Lewis, J. E. M.; Bordoli, R. J.; Denis, M.; Fletcher, C. J.; Galli, M.; Neal, E. A.; Rochette, E. M.; Goldup, S. M. Chem. Sci. 2016, 7, 3154-3161. (j) Movsisyan, L. D.; Franz, M.; Hampel, F.; Thompson, A. L.; Tykwinski, R. R.; Anderson, H. L. J. 
Am. Chem. Soc. 2016, 138, 1366-1376. (k) Neal, E. A.; Goldup, S. M. Angew. Chem. Int. Ed. 2016, 55, 12488-12493. (l) Lewis, J. E. M.; Winn, J.; Cera, L.; Goldup, S. M. J. Am. Chem. Soc. 2016, 138, 16329-16336. (m) Brown, A.; Lang, T.; Mullen, K. M.; Beer, P. D. Org. Biomol. Chem. 2017, 15, 4587-4594.

(4) Bifunctional macrocycles have been shown to accelerate nucleophilic substitutions and eliminations by stabilization of transition states, see: (a) Stanger, K. J.; Lee, J.-J.; Smith, B. D. J. Org. Chem. 20o7, 72, 9663-9668. (b) Gassensmith, J. J.; Lee, J.-J.; Noll, B. C.; Smith, B. D. New J. Chem. 2008, 32, 843-847.

(5) Internal hydrogen bonding holds the pyridine nitrogen and both amide groups in a cisoid orientation in pyridyl-2,6dicarboxyamides, compared to the more conformationally flexible isophthalamide group, see: (a) Johnston, A. G.; Leigh, D. A.; Nezhat, L.; Smart, J. P.; Deegan, M. D. Angew. Chem., Int. Ed. Engl. 1995, 34, 1212-1216. (b) Murgu, I.; Baumes, J. M.; Eberhard, J.; Gassensmith, J. J.; Arunkumar, E.; Smith, B. D. J. Org. Chem. 2011, 76, 688-691.

(6) (a) Furusho, Y.; Matsuyama, T.; Takata, T.; Moriuchi, T.; Hirao, T. Tetrahedron Lett. 2004, 45, 9593-9597. (b) Leigh, D. A.; Thomson, A. R. Org. Lett. 2oo6, 8, 5377-5379. (c) Huang, Y.-L.; Hung, W.-C.; Lai, C.-C.; Liu, Y.-H.; Peng, S.-M.; Chiu, S.-H. Angew. Chem. Int. Ed. 2007, 46, 6629-6633. (d) Zhou, W.; Xu, J.; Zheng, H.; Liu, H.; Li, Y.; Zhu, D. J. Org. Chem. 2oo8, 73, 77027709. (e) Vidonne, A.; Philp, D. Tetrahedron 2008, 64, 84648475. (f) Barrell, M. J.; Leigh, D. A.; Lusby, P. J.; Slawin, A. M. Z. Angew. Chem. Int. Ed. 20o8, 47, 8036-8039. (g) Zheng, H.; Zhou, W.; Lv, J.; Yin, X.; Li, Y.; Liu, H.; Li, Y. Chem. Eur. J. 2009, 15, 13253-13262. (h) Hung, W.-C.; Wang, L.-Y.; Lai, C.-C.; Liu, Y. H.; Peng, S. M.; Chiu, S.-H. Tetrahedron Lett. 2oo9, 50, 267-270. (i) Zhou, W.; Zhang, S.; Li, G.; Zhao, Y.; Shi, Z.; Liu, H.; Li, Y. ChemPhysChem 2009, 10, 2066-2072. (j) Muraoka, M.; Irie, H.; Nakatsuji, Y. Org. Biomol. Chem. 2010, 8, 2408-2413. (k) Chen, M.; Han, S.; Jiang, L.; Zhou, S.; Jiang, F.; Xu, Z.; Liang, J.; Zhang, S. Chem. Commun. 2010, 46, 3932-3934. (l) Hsueh, S.-Y.; Kuo, C.-T.; Lu, T.-W.; Lai, C.-C.; Liu, Y.-H.; Hsu, H.-F.; Peng, S.-M.; Chen, C.-H.; Chiu, S.-H. Angew. Chem. Int. Ed. 2010, 49, 9170-9173. (m) Hassan, N. I.; Del Amo, V.; Calder, E.; Philp, D. Org. Lett. 2011, 13, 458-461. (n) Ogawa, M.; Kawasaki, A.; Koyama, Y.; Takata, T. Polym. J. 2011, 43, 909-915. (o) Zhao, Y.; Li, Y.; Lai, S.-W.; Yang, J.; Liu, C.; Liu, H.; Che, C.-M.; Li, Y. Org. Biomol. Chem. 2011, 9, 7500-7503. (p) Spence, G. T.; White, N. G.; Beer, P. D. Org. Biomol. Chem. 2012, 10, 7282-7291. (q) Liu, L.; Liu, Y.; Liu, P.; Wu, J.; Guan, Y.; Hu, X.; Lin, C.; Yang, Y.; Sun, X.; Ma, J.; Wang, L. Chem. Sci. 2013, 4, 1701-1706. (r) Liu, P.; Li, W.; Liu, L.; Wang, L.; Ma, J. J. Phys. Chem. A 2014, 118, 9032-9044. (s) Kosikova, T.; Hassan, N. I.; Cordes, D. B.; Slawin, A. M. Z.; Philp, D. J. Am. Chem. Soc. 2015, 137, 16074-16083. (t) Marrs, C. N.; Evans, N. H. Org. Biomol. Chem. 2015, 13, 11021-11025. (u) Evans, N. H.; Gell, C. E.; Peach, M. J. G. Org. Biomol. Chem. 2016, 14, 7972-7981. (v) Fletcher, B. E.; Peach, M. J. G.; Evans, N. H. Org. Biomol. Chem. 2017, 15, 2797-2803.

(7) (a) Lohray, B. B. Synthesis 1992, 1035-1052. (b) Byun, H.-S.; He, L.; Bittman, R. Tetrahedron 20oo, 56, 7051-7091. 


90 \% $\$$

